\title{
Transactions of the Japan Society for Aeronautical and Space Sciences 揭載論文抄録
}

\author{
Vol. 10, No. 17, 1967
}

\section{1. 積層複合材における層間剪断応力の解析的研究} 林 媇 Analytical Study of Interlaminar Shear Stresses in a Laminated Composite Plate. 43-48. ロケットや航空機構造の代表的構成要素としての“積 層楧造”に扣いて，特にその各層が複合材料から作ら れる場合に，その強度を支配する因子に，層間剪断強 さがある.それは実驗的にはスパンを小さくした 3 点 曲げ試験によって求める ASTM 法があり, 多くのデ 一タが発表されているが, 層間尊断応力に関する解析 的研究は極めて少なく，かつビ一ムの理諭を出ないも のがほとんどである，そこで著者は最すよく現われる 直交三層積層板について，それが面内荷重をうりる場 合の基碟方程式を学いた，その際，各層はそれぞれ平 面応力状態を呈するとし，接着層には相隣る二層間の ずれに比例した層間欮断応力が発生すると仮定した。 一軸方向 $(x)$ に引つ張りをうける場合，そ扎に直角な $y$ 方向に起こる層間賟断応力が $q=A \operatorname{sh} \lambda y$ と表わさ れること，てれが $x$ 方向の引っ張り応力に対して相当 な大さに達しうることを例示している．また層間咅断 応力の影響を考慮に入れて求めた積層板のより一般な ポアソン比の式す導いている.

2. 断面に亘って不均一な温度分布をうける柱のク リープ座屈 林 毅 Creep Buckling of a Column under Non-uniform Temperature Distribution over it's Sections. 49-53. 著者らの前の論文 (Trans. Japan Soc. Aero. Space Sci. Vol. 8, 12 (1965), p. 15/22）に执いては，軸方向に不均一な温度分布が， 柱のクリープ座屈に及ぼす影響を解析した．本論文で は柱の断面に亘って不均一な温度分布をうりる場合に ついて，それが圧縮クリープ座届に及ぽす影暃を先の 論文で著者が導入したガラーキン法によって解析し t.

この解析から，2 フランジから成る柱についてある 初期撓みを仮定するとき，フランジの温度差がその初 期撓みを增大させる万向に与えられる場合にはクリ一 プ座屈時間が著しく減少すること，またその温度差が 逆の場合には反対にクリープ時間は増大することが見 出された。

3. 瀻維強化複合材料のクリープ強さの複合則 林 教 On the Law of Mixture of Creep Strength of Fiber Reinforced Composite Materials. 54-58.
連続纎維による一方向強化複合材料の引っ張りクリー プ強さの解析を行ない, クリープ強さに関军る簡単な 複合則を導いた。

グラス・ファイバーで強化したプラスチックスや， タングステン，ファイバーで強化した銅に対してそれ らの複合則の式を導いている. ウィートンとシグノレ リによるタングステン強化銅のクリープ試験結果との 比較は良好な一致を示す。

4. 単純支持矩形板の超音速パネル・フラッターに 対する盆断力, 剪断座屈変形の影響 小林繁夫, 平岡 康一 Influence of Shearing Force and Shear Buckling Deformation on Supersonic Panel Flutter of Simply Supported Rectangular Plates. 59-69.

一面が超音速流に暴された周辺単純支持矩形板の超音 速パネル・フラッター限界值に対する剪断力さらに斯 断座屈変形の影響について，薄板の有限変形理論之準 定常空気力を用い，GALERKIN 法4 項近似を用いて解 析的研究を行なったものである. 数値計算は正方形板 について行なった．フラッター限界值を動正比 $Q=$ $\rho_{0} V^{2} a^{3} /\left(V \overline{M^{2}-1} D \pi^{4}\right.$ ( $\rho_{0}$ : 空気密度, $V$ : 流速, $M$ : マッ八数， $a$ : 板の辺長， $D$ : 板の曲げ剛性）で表わ す之，筧断力の作用により平らな状態の動的安定限界 としての $Q_{c v}$ は低下するが, 座屆変形を起こした後 は剪断力したがって座厥変形量の増大とと向に，撓ん だ平衡状態の安定限界としての $Q_{c r}$ が增大するので, 岦断座屈応力よりあ少し高い所で $Q_{c r}$ の最小值が現わ れ，その值は 1.4 である.てれは著者がさきに求めた 2 方向同じ大きさで一様圧縮して座屈変形を起てす場合 の $\left(Q_{c r}\right)$ 最小值二1.8 よりす低く, SYLVESTER が実驗 で見出したととに理論的な説明を与えるすのである. さらに，板面内の応力状態を撓み=0 の状態での流れ の方向の正縮応力 $\sigma_{10}$ とそれに直角方向の正縮応力 $\sigma_{20}$ と剪断応力 $\tau_{0}$ で表わす之，剪断応力 $\tau_{0}$ の他にとれら $\sigma_{10}, \sigma_{20}$ が同時に作用した場合として $\sigma_{20} / \sigma_{10}=1,0$, $-3 / 7,-1 の 4$ 通りの場合についてパネル・フラッタ 一限界值 $Q_{0}$ の $\sigma_{10}, \tau_{0}$ による变化を求め，乙れらの パラメータにより $Q_{\text {cr }}$ が大きく変わるととを示してい る. $\sigma_{20}$ 加負即ち引っ張り応力の場合， $\sigma_{10}, \tau_{0}$ の值に

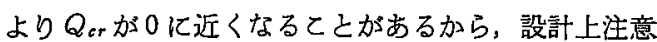
しなければならない。

5. 単純支持矩形板の超音速パネル・フラッターに 
対する初期撓みおよび内圧の影響 小林繁夫, 松崎雄 嗣 Influence of Initial Deflectiou and Internal Pressure on Supersonic Panel Flutter of Simply Supported Rectangular Plates. 70-77. 周辺単純 支持矩形板の超音速パネル・フラッター限界值に対す る板の初期撓みおよび上下面の静王力差の影響につい て，薄板の有限变形理論之準定常空気力を用い， $\mathrm{GA}^{-}$ LERKIN 法 2 項近似を用いて解析的研究を行なったも のである，板の初期撓みとしては，流れに直角方向に は正弦波 1 半波で流れの方向には正弦波の 1 半波と 2 半波の 2 項の和（それぞれ 1 次および 2 次の初期撓み と名付ける）を仮定している．板面内の応打状態は撓 み量を初期撓みと同じに保ったときに生ずる中央面の 流れの方向および流れに直角方向の圧縮応力 $\sigma_{10}, \sigma_{20}$ で表わし， $\sigma_{20} / \sigma_{10}=1,0,-3 / 7,-1$ の 4 通りの場合に ついて，動圧比を緃軸に，無次元化した $\sigma_{10}$ を横軸に
とって, 1 次および 2 次の初期撓みと上下面静庄力差 の3つをパラメータとして安定限界線を求め図示し た．微小な初期挸みおよび静圧力差がパネル・フラッ タ一限界值に大さな影響を与えるととが明らかにされ ている.したがって実倹に当たっては初期㮱み静圧力 差の値に注意しなければならない.これらの影響は, $\sigma_{20} / \sigma_{10}$ と $\sigma_{10}$ の值によりまた初期撓み静圧力差 $3 つ$ のパラメータの組み合わせによりかなり複雑に変化す るので単純な結論を示すことは出来ないが，1次の初 期撓みと静圧力差は安定化の傾向をむっている. 1 次 の座屆変形を起こす面内力の状態で， 2 次の初期撓み は部分的に不安定化の影響をむつ安定限界線を作る. 数值的には静圧力差の影響が最も大きく，静圧力差は その值がかなり小さくてもパネル・フラッター防止に 非常に役立つことが示されている。
表紙写真説明

VTOL 機の垂直﨎着陸およびホバリング飛行を研 究するための実験機，フライング・テスト・ベッドが 完成した.

\section{主要諸元}

全長 $10 \mathrm{~m}$, 全幅 $7 \mathrm{~m}$, 全高 $3 \mathrm{~m}$,

全備重量 約 $1,900 \mathrm{~kg}$

乗員 1 名

エンジン JR100 Fリフト・エンジン 2 基

飛行時間 約 10 分間

本機の飛行中の高度制御はリフト・エンジンの推力 制御で行ない，姿勢制御は機体前後・左右端の空気シ エット・ノズルからの吹き出し空気（エのジンよりの
抽気）を制御することで行なうが，これらの制御ため の自县安定装置を搭载している.

（航空宇宙技術研究所）



